\title{
Use of coccidiostat in mineral salt and study on ovine eimeriosis
}

\author{
Uso de coccidiostático no sal mineral e estudo da eimeriose ovina \\ Alberto Luiz Freire de Andrade Júnior ${ }^{1 *}$; Patrícia Costa da Silva ${ }^{1}$; Emerson Moreira de Aguiar ${ }^{1}$; \\ Francisco Glauco de Araújo Santos ${ }^{1}$
}

${ }^{1}$ Unidade Acadêmica Especializada em Ciências Agrárias, Universidade Federal do Rio Grande do Norte - UFRN

Received February 24, 2011

Accepted September 27, 2011

\begin{abstract}
Coccidiosis is a serious obstacle to sheep production, which is becoming a limiting factor, especially with regard to lamb production. However, there are few studies on this parasite in the State of Rio Grande do Norte. The aim of this study was to evaluate the action of decoquinate, added to mineral salt, for controlling Eimeria infection in lambs, and to identify which species are infecting sheep in the eastern region of the state. This study was carried out from August 2009 to January 2010, and used 76 animals. These were divided into two treatment groups: one with common mineral salt, and the other with mineral salt enriched with $6 \%$ micronized decoquinate. Fecal samples and body weight measurements were taken every 14 days for parasitological diagnosis, weight gain follow-up and quantitative analysis. The study showed that there was a significant difference in OPG only at the $7^{\text {th }}$ collection, but no significant difference in weight gain. The Eimeria species found were E. ahsata, E. crandallis, E. granulosa, E. intrincata, E. ovina, E. faurei, E. ovinoidalis, E. pallida and E. parva. It was concluded that addition of decoquinate to mineral salt gave rise to lower oocyst elimination, thus favoring eimeriosis control in sheep.
\end{abstract}

Keywords: Eimeriosis, lambs, coccidiostatic, mineral salt, Macaíba - RN.

\section{Resumo}

A coccidiose constitui-se num sério obstáculo à ovinocultura, a qual vem se tornando um fator limitante para a exploração, especialmente para a produção de cordeiros precoces. Porém, poucos são os estudos com esse parasito no Estado do Rio Grande do Norte. O objetivo deste trabalho foi avaliar a açáo do decoquinato, adicionado ao sal mineral, no controle da infecção causada por parasitas do gênero Eimeria em cordeiros, e identificar quais as espécies infectam ovinos na região leste Potiguar. O trabalho foi desenvolvido entre agosto de 2009 e janeiro de 2010, e foram usados 76 animais, distribuídos em dois tratamentos, um com sal mineral comum e o outro com sal mineral enriquecido com decoquinato a $6 \%$ micronizado. Amostras fecais e pesagens dos animais foram feitas a cada 14 dias para o diagnóstico parasitológico, acompanhamento do ganho de peso ponderal e análise quantitativa. O estudo evidenciou que houve diferença significativa na redução do OoPG apenas na $7^{\circ}$ semana de experimento, mas não houve diferenças significativas para ganho de peso dos animais. As espécies encontradas foram E. ahsata, E. crandallis, E. granulosa, E. intrincata, E. ovina, E. faurei, E. ovinoidalis, E. pallida e E. parva. Conclui-se que a adição de decoquinato ao sal mineral propiciou uma menor eliminaçáo de oocistos favorecendo o controle da eimeriose ovina.

Palavras-chave: Eimeriose, cordeiro, coccidiostático, sal mineral, Macaíba - RN.

\section{Introduction}

Sheep farming is a traditional activity in northeastern Brazil, but sanitary problems still exist, and these are largely to blame for the low zootechnical and economic performance of the herds and are factors that limit increased productivity. Economic losses

${ }^{*}$ Corresponding author: Alberto Luiz Freire de Andrade Júnior Departamento de Agropecuária, Centro de Tecnologia,

Universidade Federal do Rio Grande do Norte - UFRN, Campus Universitário

Lagoa Nova, CP 1524, CEP 59078-970, Natal, RN, Brazil

e-mail: alufranju@hotmail.com from mortality and unsatisfactory performance are caused mainly by parasites like those responsible for coccidiosis, which is one of the main diseases harming the breeding of small ruminants. Mortality in young animals affected by eimeriosis is high under certain circumstances, sometimes reaching rates of more than 20\% (VIEIRA, 2002).

These animals are parasitized by a large number of Eimeria species with marked host specificity, and young animals have greatest susceptibility (VIEIRA, 2002; LIMA, 2004; LAGARES, 
2008). Eimeria species found in the State of Rio Grande do Norte were first studied by Ahid et al. (2009), in the municipality of Mossoró, in the western part of the state, but there are no reports about which species infect sheep in the other regions.

A large number of drugs have been recommended for treating coccidiosis in ruminants. They can be added to feed, water or mineral salt and, depending on the drug, its use can be continuous or strategically periodic. Among the most widely use are sulfa, amprolium (SANTIAGO et al., 1977), decoquinate, antibiotics, ionophores (monensin, salinomycin and lasalocid) (HEINRICHS; BUSH, 1991; WAGGONER et al., 1994; NUSSIO et al., 2002; VIEIRA et al., 2004; VIEIRA et al., 2005; LIMA et al., 2009) and toltrazuril (SANTIAGO et al., 1977; SILVA et al., 2007). Decoquinate interrupts the development of coccidians from the outset of their life cycle, by acting on the first stages of their lives to delay their development before they can cause any intestinal damage over the entire period of their life cycle in the small intestine. This period represents $71 \%$ of the protozoan cycle in the host.

In light of the need to study ways of preventing coccidiosis or eimeriosis in the State of Rio Grande do Norte (RN), the aims of the present study were to evaluate the efficiency of decoquinate in mineral salt fed to lambs, for preventing and controlling ovine eimeriosis and for promoting growth and weight development among these animals, and to identify which Eimeria species infect these animals, in the municipality of Macaíba in the eastern portion of Rio Grande do Norte.

\section{Material and Methods}

The experiment took place in the municipality of Macaíba, $\mathrm{RN}$, in the eastern mesoregion of the state, from August 2009 to January 2010. The examinations were done at the Animal Parasitology Laboratory, Animal Nutrition Laboratory and Aquatic Microbiology Laboratory of the Federal University of Rio Grande do Norte (UFRN).

A total of 76 crossbred Santa Inês-Dorper lambs (32 males and 44 females), aged seven days, were randomly selected and divided into two groups: group T1, without the coccidiostat (control group), and group T2, with the coccidiostat (treated group). They were given water and mineral salt, with or without the coccidiostat, ad libitum, depending on the group to which they belonged.

All the animals were weighed every two weeks. Using a surgical glove, feces were collected directly from the rectal ampoule, and were placed inside duly identified plastic collectors, packed in Styrofoam containers and sent for oocyst examination and induced sporulation.

The feces were evaluated by means of the floatation technique in saturated sugar solution. Quantitative analysis was done using the oocyst per gram of feces (OPG) counting method, in accordance with the technique developed by Gordon and Whitlock (1939), as modified by Ueno and Gonçalves (1998).

Positive fecal material from animals belonging to the same group (T1 or T2, separately) was subjected to qualitative analysis, using induced sporulation of oocytes in an aqueous solution of feces added to a solution of $2.5 \%$ potassium dichromate $\left(\mathrm{K}_{2} \mathrm{Cr}_{2} \mathrm{O}_{7}\right)$, at proportions of one part of feces to two parts of potassium dichromate. Next, the mixture was passed through sieves to remove any fragments and poured in fine layers into Petri dishes. It was then sporulated at ambient temperature for 10 days for later identification of Eimeria species according to morphological traits (SILVA et al., 2007; SKIRNISSON, 2007; TOULAH, 2007; YAKHCHALI; GOLAMI, 2008; AHID et al., 2009).

After sporulation, the material was centrifuged and the oocysts were suspended in a saturated sugar solution, placed between a slide and coverslip and identified based on morphology and sporulated oocyst measurements. Two hundred random oocysts (100 from group T1 and 100 from group T2) were morphometrically studied (measured using an ocular micrometer with a 100x lens) to identify each species. The criteria adopted for differentiating the species were based on color, presence or absence of an operculum and oocyte size (REGINSSON; RICHTER, 1997; FREITAS et al., 2005; SILVA et al., 2007; AHID et al., 2009; DENIZ, 2009). All the measurements were presented as mean \pm SD.

The mean number of oocysts in T2 feces was calculated and compared with the mean found in $\mathrm{T} 1$, and this was also done for the animals' weights. Before analysis of variance (ANOVA) was performed, it was found that the OPG variable did not obey normal distribution. The following logarithmic transformation was used to stabilize occurrences of OPG: OPGT $=\log (\mathrm{OPG}+20)$.

The least-squares method was used in analysis of variance, in which the statistical model used for OPG and for weight was: $y_{i j k}=\mu+t_{i}+a_{j}\left(t_{i}\right)+c_{k}+(t c)_{i k}+e_{i j k}$, where $y$ is the $\mathrm{k}^{\text {th }}$ observation of OPG or of weight, in the $\mathrm{i}^{\text {th }}$ treatment on the $\mathrm{j}^{\text {th }}$ animal; $\mu$ is the parametric mean; $t$ is the fixed effect of the $\mathrm{i}^{\text {th }}$ treatment $(i=1,2)$; $a$ is the effect of the $j^{\text {th }}$ animal on the $i^{\text {th }}$ treatment; $c$ is the effect of the $k^{\text {th }}$ observation of OPG or of weight; $t c$ is the effect of the interaction between the $i^{\text {th }}$ treatment and the $k^{\text {th }}$ observation of OPG or of weight; and $e_{i j k}$ is the random error. All the analyses were conducted using the SAS software (2001).

\section{Results and Discussion}

During the experiment, a significant treatment difference ( $p<0.05$ ) was observed only in relation to the reduced OPG count (Table 1) in the $7^{\text {th }}$ collection week. However, in some weeks, the OPG count in group T2 was lower than that of group T1 (Figure 1), thus resulting in a lower overall mean for T2 than for T1. It should be pointed out that this slight difference between treatments may have been due to the food given to the animals, given that they received nutritional supplementation, which promotes a certain degree of immunological development, thereby contributing towards eimeriosis control.

According to Lima (2004), the treatment for this disease, when specific drugs are used, is efficient if it is applied early. The treatment is effective and yields good results when used at the onset of the disease, since most drugs act on the early stages of coccidian multiplication.

Despite the high OPG values observed, clinical symptoms of eimeriosis were found in the groups only in the first weeks, when the lambs were still being nursed. From the $8^{\text {th }}$ week of the experiment $\left(5^{\text {th }}\right.$ collection $)$, no clinical symptoms were detected 
Table 1. Mean number of OPG in sheep in 11 assessments. Data transformed to $\log (\mathrm{OPG}+20)$. (T1 = Control group; $\mathrm{T} 2=$ Treated group).

\begin{tabular}{|c|c|c|}
\hline Collections & T1 & T2 \\
\hline 1 & $1.66^{\mathrm{aA}}$ & $1.79^{\operatorname{abcdefg} A}$ \\
\hline 2 & $2.56^{\mathrm{abcd} A}$ & 2.22 abcde A \\
\hline 3 & $1.95^{\mathrm{cde} A}$ & $1.30^{\mathrm{g} \mathrm{A}}$ \\
\hline 4 & $2.63 \mathrm{abcA}$ & $1.89^{\operatorname{abcdefg} A}$ \\
\hline 5 & $1.84 \mathrm{de} A$ & $1.60 \operatorname{adefg} A$ \\
\hline 6 & $2.10^{\text {bcde A }}$ & $2.14^{\text {abcdef A }}$ \\
\hline 7 & $2.68^{a b A}$ & 1.74 acdefg B \\
\hline 8 & $2.99^{\mathrm{aA}}$ & $2.45 \mathrm{abcA}$ \\
\hline 9 & $2.19^{\text {bcde A }}$ & $2.50 \mathrm{ab} A$ \\
\hline 10 & 2.38 abcde A & $2.58^{\mathrm{aA}}$ \\
\hline 11 & $1.78^{\mathrm{eA}}$ & $2.27 \mathrm{abcd} A$ \\
\hline Mean & $2.25^{\mathrm{A}}$ & $2.04^{\mathrm{A}}$ \\
\hline
\end{tabular}

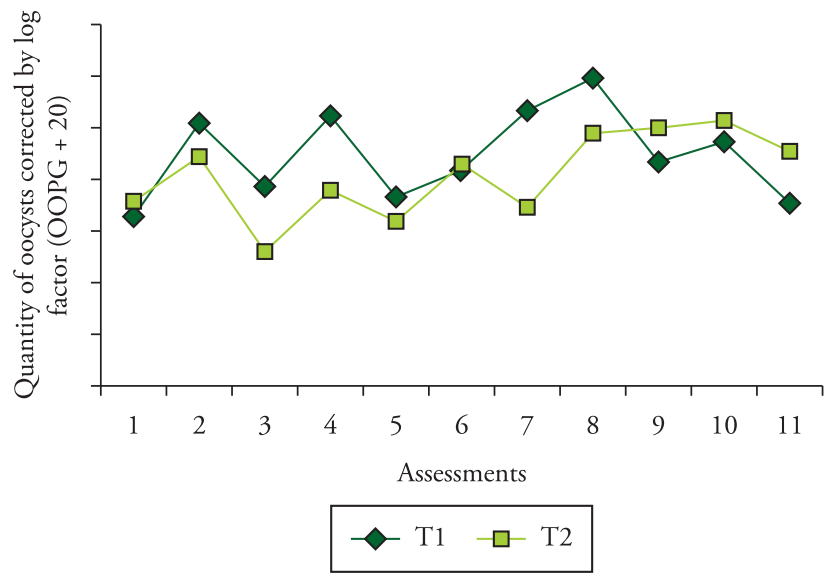

Figure 1. Results from oocyst examinations on the lambs, according to treatments, corrected using the log factor $(\mathrm{OPG}+20)(\mathrm{p}<0.05)$, in 11 assessments.

in either of the groups. This may have been due to parasitism by non-pathogenic Eimeria species or because of the small numbers of pathogenic species. Several authors have reported that high population density may be responsible for massive contaminations, and have confirmed that young animals are more susceptible to coccidiosis than are older individuals, in any animal species (MENEZES; LOPES, 1997; REGINSSON; RICHTER, 1997; HASSUM et al., 2002; BARBOSA et al., 2003; FREITAS et al., 2005; HASSUM; MENEZES, 2005; SARTOR et al., 2007; TOULAH, 2007; YAKHCHALI; GOLAMI, 2008).

The first sign that the disease has spread throughout the herd is the fact that the lambs are not developing as expected. In addition to presenting with pleated skin and loss of wool, some of the animals show feces on the hindquarters, due to diarrhea (DENIZ, 2009).

The diagnosis of coccidiosis is based on anamnesis, in which information on handling and the rearing system, clinical signs, macroscopic lesions at necropsy, presence of endogenous forms of the parasite in the affected tissues and feces examination is correlated (LIMA, 2004). The prophylaxis for the disease very often consists of eliminating overcrowded conditions and fecal contamination of drinking water or food. Improved hygiene and sanitation conditions reduce the infection level and incidence of clinical outbreaks (DENIZ, 2009).

The pathogenic effects of eimeriosis on sheep production are stronger among animals raised in intensive systems, in which animal concentrations are much higher than in extensive systems. The infection may be asymptomatic, according to the species of Eimeria, seriousness and rate of acquiring the disease, age of the animal and the presence or absence of predisposing factors. Thus, the coccidiosis may be clinical or subclinical, and may or may not exhibit clinical symptoms. Both the clinical and the subclinical form of the disease compromise animal health, possibly leading to their death (LAGARES, 2008). The most serious form of coccidiosis is characterized by severe diarrhea, dehydration, anorexia, lethargy and a high mortality rate (LIMA, 2004). Subclinical coccidiosis is the most common form of the disease and, even though the losses are imperceptible to the producer, they are significant and may have greater economic impact than losses due to death or clinical manifestations.

The quantitative OPG analysis was followed by qualitative assessment using sporulation to identify Eimeria species. The species found were E. ovina (9.0\%); E. ahsata (4.0\%); E. crandallis (19.0\%); E. faurei (4.0\%); E. intrincata $(2.0 \%)$; E. ovinoidalis (15.0\%); E. pallida (17.0\%); E. parva (21.0\%); and E. granulosa $(9.0 \%)$ (Figure 2). These results are in partial agreement with those obtained by Ahid et al. (2009), in the municipality of Mossoró, which is located in the western part of the state. They did not find the species $E$. pallida or E. intrincata, but they did identify E. caprovina, a species that was not observed in the present study. Therefore, the present investigation can be considered to be a pioneering study on ovine eimeriosis in western Rio Grande do Norte.

The morphometric assessments on oocysts from Eimeria species found in the lambs of the present study (Table 2) are similar to those observed by Ahid et al. (2009), with a slight difference for E. faurei, E. crandallis and E. granulosa, such that the previous authors recorded a larger polar diameter. They also reported slight individual differences. However, the oocyst dimensions should be considered to be specific characteristics.

Ovine coccidiosis is present in practically all the countries where sheep are raised. In addition to this, many papers have shown that some Eimeria species are found more often than others: E. parva, E. ahsata, E. faurei, E. ovinoidalis, E. crandallis, E. intrincata, E. bakuensis, E. granulosa, E. pallida, E. ovina, E. weybridgensis, E. punctata, E. caprovina, E. arloingi, E. marsica, and E. ninaekohlyakimovi (TORRES, 1945; SILVA et al., 1987; AMARANTE et al., 1993; HIDALGO-ARGÜELLO et al., 1997; REGINSSON; RICHTER, 1997; KAYA, 2004; HASSUM; MENEZES, 2005; RIVERA et al., 2005; SILVA et al., 2007; SKIRNISSON, 2007; TOULAH, 2007; SILVA et al., 2008; YAKHCHALI; GOLAMI, 2008; AHID et al., 2009).

The species E. ovinoidalis is considered to be the most pathogenic of the species, capable of causing death in male lambs, followed by E. crandallis. Although the latter is only moderately pathogenic, 


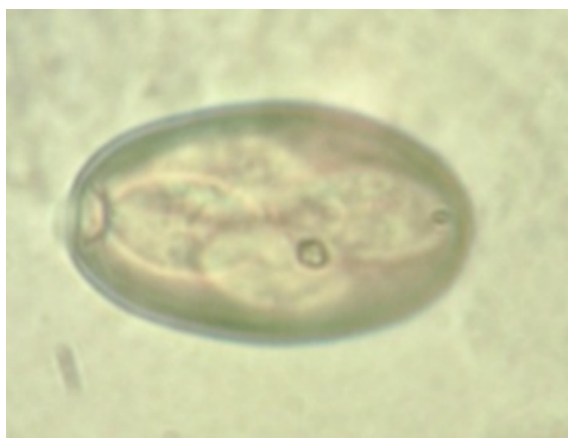

E. ahsata

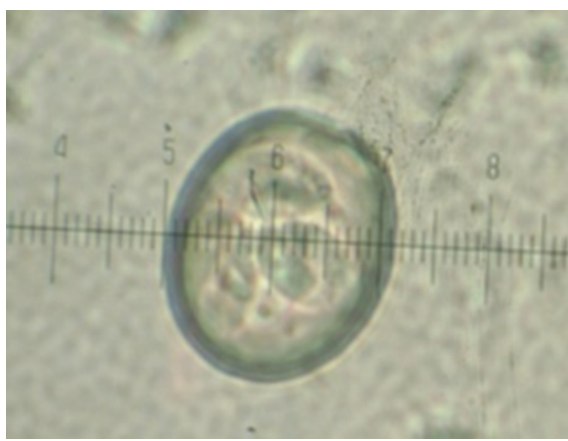

E. ovinoidalis

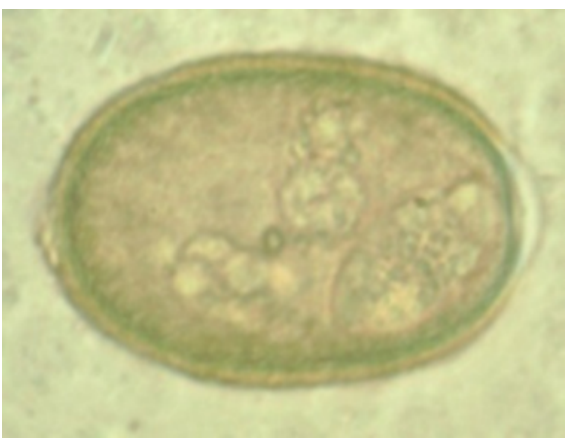

E. intrincata

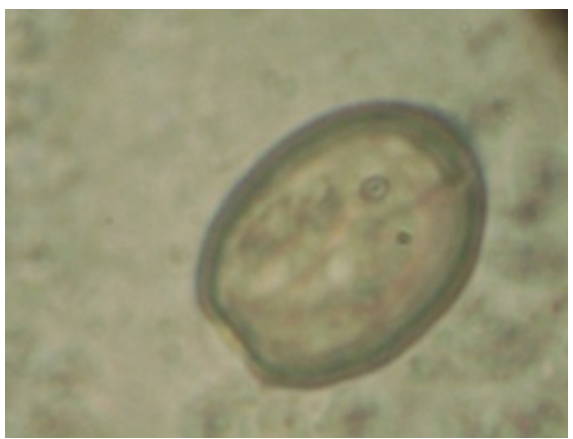

E. pallida

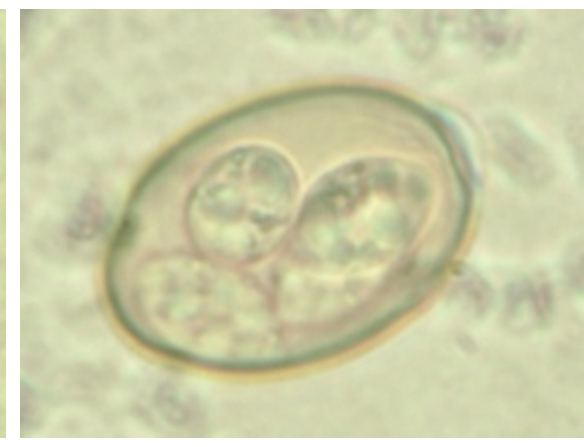

E. granulosa

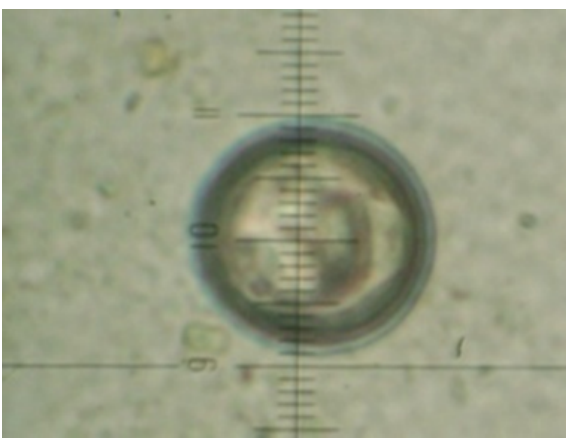

E. parva

Figure 2. Some species of Eimeria were identified in the feces of lambs raised in an intensive system in the eastern part of Rio Grande do Norte.

Table 2. Morphometric indices of sporulated oocysts from Eimeria species in lambs raised in an intensive system in the municipality of Macaíba, Rio Grande do Norte, Brazil.

\begin{tabular}{lcccc}
\hline \multirow{2}{*}{ Eimeria species } & Operculum & \multicolumn{3}{c}{ Oocysts $(\mu \mathrm{m})$} \\
\cline { 3 - 5 } & & \multicolumn{3}{c}{ Diameters } \\
\cline { 3 - 5 } & Yes & $31.88 \pm 3.56$ & $22.00 \pm 3.12$ & Equatorial \\
\hline E. ahsata & Yes & $22.41 \pm 2.60$ & $18.46 \pm 2.08$ & $1.46 \pm 0.14$ \\
E. crandallis & Yes & $24.88 \pm 1.76$ & $19.41 \pm 2.06$ & $1.22 \pm 0.12$ \\
E. intrincata & Yes & $50.20 \pm 5.72$ & $38.20 \pm 2.95$ & $1.29 \pm 0.12$ \\
E. ovina & Yes & $30.61 \pm 0.98$ & $21.78 \pm 2.05$ & $1.31 \pm 0.11$ \\
E. faurei & No & $26.89 \pm 2.37$ & $20.56 \pm 0.73$ & $1.42 \pm 0.12$ \\
E. ovinoidalis & No & $23.21 \pm 3.06$ & $18.41 \pm 2.41$ & $1.31 \pm 0.10$ \\
E. pallida & No & $15.70 \pm 1.70$ & $12.30 \pm 1.40$ & $1.27 \pm 0.14$ \\
E. parva & No & $18.98 \pm 3.87$ & $17.17 \pm 3.46$ & $1.29 \pm 0.17$ \\
\hline
\end{tabular}

it exacerbates the pathogenic effects of the former. E. bakuensis is equally pathogenic, especially in the asexual phase. E. parva is a mildly pathogenic species. Under experimental conditions, $E$. ahsata is highly pathogenic. The pathogenicity of E. faurei, E. intrincata and $E$. weybridgensis remains unknown (LAGARES, 2008; SILVA et al., 2008).

With regard to weight gain, decoquinate was not found to have any statistical influence $(p>0.05)$ over the course of the experiment (Figure 3). However, group T2 animals gained more weight than group T1 animals (difference of $2.829 \mathrm{~kg}$ ).

Further studies should be performed using decoquinate, with the aim of determining what percentage supplementation of this coccidiostat in the diet of lambs provides efficient weight gain.

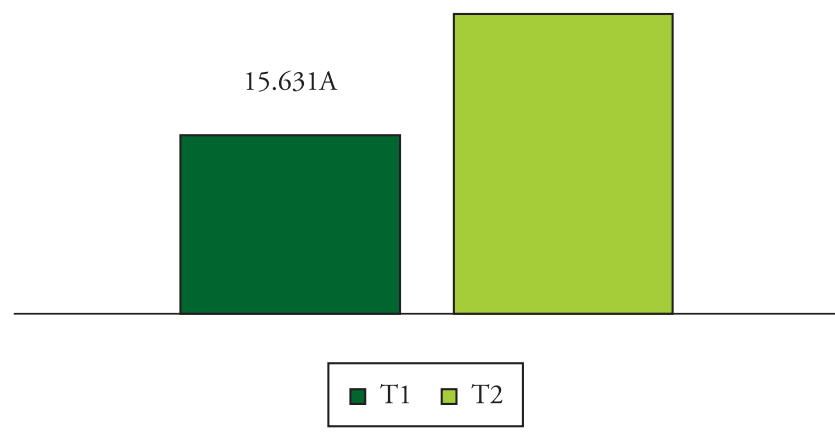

Figure 3. Mean weight gain of lambs according to treatment. 


\section{Conclusion}

Preventive treatment with decoquinate, added to mineral salt, was efficient in preventing clinical and subclinical coccidiosis, but did not result in maximum weight gains in the treated lambs. On the other hand, it always produced better outcomes than among untreated animals.

The following Eimeria spp. species were identified: E. ovina; E. ahsata; E. crandallis; E. faurei; E. intrincata; E. ovinoidalis; E. pallida; E. parva; and E. granulosa. This was a pioneering study with regard to identifying coccidian species in the eastern region of the State of Rio Grande do Norte, Brazil.

\section{Acknowledgements}

To the Sal Leão company for providing the mineral salt and support for the study and the São Joaquim farm for providing the infrastructure and access to the animals.

\section{References}

Ahid SMM, Medeiros VMC, Bezerra ACDS, Maia MB, Lima VXM, Vieira LS. Espécies do gênero Eimeria Schneider, 1875 (Apicomplexa: Eimeriidae) em pequenos ruminantes na Mesorregião Oeste do estado do Rio Grande do Norte, Brasil. Cienc Anim Bras 2009; 10(3): 984-989.

Amarante AFT, Barbosa MA, Sequeira JL. Coccidiose em cordeiros em Botucatu - SP, relato de dois casos. Rev Bras Parasitol Vet 1993; 2(1): 73-74.

Barbosa PBB, Vieira LS, Leite AI, Braga AP. Espécies do gênero Eimeria Schneider, 1875 (Apicomplexa: Eimeriidae) parasitas de caprinos no município de Mossoró, Rio Grande do Norte. Cienc Anim 2003; 13(2): 65-72.

Deniz A. Coccidiose ovina: revisão bibliográfica. Albéitar 2009; 3: 4-11.

Freitas FLC, Almeida KS, Nascimento AA, Machado CR, Veschi JLA, Machado RZ. Espécies do gênero Eimeria Schneider, 1875 (Apicomplexa: Eimeriidae) em caprinos leiteiros mantidos em sistema intensivo na regiâo de São José do Rio Preto, estado de São Paulo, Brasil. Rev Bras Parasitol Vet 2005; 14(1): 7-10.

Gordon HMcL, Whitlock HV. A new technique for counting nematode eggs in sheep faeces. J Counc Sci Ind Res 1939; 12: 50-52.

Hassum IC, Menezes RCAA. Infecção natural por espécies do gênero Eimeria em pequenos ruminantes criados em dois municípios do estado do Rio de Janeiro. Rev Bras Parasitol Vet 2005; 14(3): 95-100.

Hassum IC, Paiva RV, Menezes RCAA. Freqüência, dinâmica e morfologia dos oocistos de Eimeria bakuensis (Apicomplexa: Eimeriidae) em ovinos de diferentes categorias de produção de uma criação no município de Petrópolis/RJ. Rev Bras Parasitol Vet 2002; 11(1): 19-25.

Heinrichs AJ, Bush GJ. Evaluation of decoquinate or lasalocid against coccidiosis from natural exposure in neonatal dairy calves. J Dairy Sci 1991; 74(9): 3223-3227. http://dx.doi.org/10.3168/jds.S00220302(91)78508-1

Hidalgo-Argüello MR, González C, Manga MY, Martínez MC. Ovine coccidia in the porma river basin (León, Spain). Res Rev Parasitol 1997; 57(2): 127-130.
Kaya G. Prevalence of Eimeria species in lambs in Antakya Province. Turk J Vet Anim Sci 2004; 28: 687-692.

Lagares AFBF. Parasitoses de pequenos ruminantes na regiáo da Cova da Beira [Dissertação]. Lisboa: Faculdade de Medicina Veterinária, Universidade Técnica de Lisboa; 2008.

Lima JD. Coccidiose dos ruminantes domésticos. Rev. Brasil. Parasitol. Vet. 2004; 13: suplemento 1, p. 9-13.

Lima VXM, Ahid SMM, Simplicio AA. Efeito de sal mineral enriquecido ou não com ionóforos sobre a frequência de eimeriídeos de fêmeas caprinas jovens. Rev Agroneg Meio Amb 2009; 2(2): 63-71.

Menezes RCAA, Lopes, CWG. Eimeria alijevi (Apicomplexa: Eimeriidae) em caprinos leiteiros na Microrregiāo Serrana Fluminense, RJ. Rev Bras Parasitol Vet 1997; 6(1): 69-73.

Nussio CMB, Huber JT, Nussio LG. Decoquinate, lasalocid and monensin for starter feeds and the performance of Holstein calves to 20 weeks of age. Sci Agric 2002; 59(3): 421-426. http://dx.doi. org/10.1590/S0103-90162002000300002

Reginsson K, Richter SH. Coccidia of the genus Eimeria in sheep in Iceland. Icel Agr Sci 1997; 11: 99-106.

Rivera OC, Trón JL, Arellano TL, Pérez, J. Utilización de bolos ruminales de liberación de sulfametazina sódica em El control de La coccidiosis ovina. Arq Ciên Vet Zool 2005; 8(2): 147-153.

Santiago MAM, Costa UC, Silva OL. Investigaçáo sobre a coccidiose ovina. Rev Cent Cienc Rurais 1977; 7(3): 297-301.

Sartor AA, Bellato V, Souza AP, Cantelli CR. Prevalência das espécies de Eimeria Schneider, 1875 e Isospora Schneider, 1881 (Apicomplexa: Eimeriidae) parasitas de suínos do município de Videira, SC, Brasil. Rev Cienc Agrovet 2007; 6(1): 38-43.

SAS Institute. User's guide. Cary: SAS Institute; 2001.

Silva NRS, Araujo FA, Chaplin EL. Eimerídios de ovinos constatados no município de Porto Alegre. Arq Fac Vet UFRGS 1987; 15(16): 41-45. http://dx.doi.org/10.1590/S0102-09352007000600018

Silva TP, Facury Filho EJ, Nunes ABV, Albuquerque FHMAR, Ferreira PM, Carvalho AU. Dinâmica da infecção natural por Eimeria spp. em cordeiros da raça Santa Inês criados em sistema semi-intensivo no Norte de Minas Gerais. Arq Bras Med Vet Zootec 2007; 59(6): 1468-1472.

Silva FRC, Souza JD, Fialho CG, Escopeli KS, Araújo FAP. Identificação das espécies de Eimeria spp. em ovinos no município de Mostardas/RS. Vet Foco 2008; 6(1): 16-20.

Skirnisson K. Eimeria spp. (Coccidia, Protozoa) infections in a flock of sheep in Iceland: species composition and seasonal abundance. Ice. Agric Sci 2007; 20: 73-80

Torres S. Doenças de caprinos e ovinos no Nordeste Brasileiro. Rio de Janeiro: Serviço de Informação Agrícola; 1945.

Toulah FH. Prevalence and comparative morphological study of four Eimeria sp. of sheep in Jeddah Area, Saudi Arabia. J Biol Sci 2007; 7(2): 413-416. http://dx.doi.org/10.3923/jbs.2007.413.416

Ueno H, Gonçalves PC. Manual para diagnóstico das helmintoses de ruminantes. $4^{\text {nd }}$ ed. Tóquio: Japan International Cooperation Agency, 1998.

Vieira LS. Eimeriose de pequenos ruminantes: panorama da pesquisa no Nordeste do Brasil. Sobral: Embrapa Caprinos; 2002. 
Vieira LS, Barros NN, Cavalcante ACR, Ximenes LJF, Carvalho RB. A salinomicina para o controle da eimeriose de caprinos leiteiros nas fases de cria e recria. Cienc Rural 2004; 34(3): 873-878. http://dx.doi. org/10.1590/S0103-84782004000300033

Vieira LS, Lobo RNB, Barros NN, Portela CHP, Simplício AA. Monensina sódica no controle da eimeriose em caprinos leiteiros. Cienc Anim 2005; 15(1): 25-31.
Waggoner JK, Cecava MJ, Kazacos KR. Efficacy of lasalocid and decoquinate against coccidiosis in naturally infected dairy calves. J Dairy Sci 1994; 77(1): 349-353. http://dx.doi.org/10.3168/jds.S00220302(94)76961-7

Yakhchali M, Golami E. Eimeria infection (Coccidia: Eimeriidae) in sheep of different age groups in Sanandaj city, Iran. Vet Arhiv 2008; 78(1): 57-64. 